\title{
An ethnomycological survey of macrofungi utilized by Aeta communities in Central Luzon, Philippines
}

\author{
De Leon $\mathrm{AM}^{1,3}$, Reyes $\mathrm{RG}^{3}$ and dela Cruz TEE ${ }^{1,2^{*}}$ \\ ${ }^{1}$ Graduate School, and ${ }^{2}$ Department of Biological Sciences, College of Science, University of Santo Tomas, España \\ 1015 Manila, Philippines \\ ${ }^{3}$ Department of Biological Sciences, College of Arts and Sciences, Central Luzon State University, 3120 Science City \\ of Muñoz, Nueva Ecija, Philippines
}

De Leon AM, Reyes RG, dela Cruz TEE - An ethnomycological survey of macrofungi utilized by Aeta communities in Central Luzon, Philippines. Mycosphere 3(2), 251-259, Doi 10.5943/mycosphere/3/2/9

Questionnaires and formatted interviews were used to determine mushrooms used as food and as materials for societal rituals and beliefs among six Aeta communities in three provinces of Central Luzon, Northern Philippines. Thirty-eight different fungi were utilized by the Aeta communities: 21 in Pampanga, 10 in Tarlac, and 19 in Zambales. Fourteen fungal species were collected and identified based on their morphological characters: Auricularia auricula, A. polytricha, Calvatia sp., Ganoderma lucidum, Lentinus tigrinus, L. sajor-caju, Mycena sp., Pleurotus sp., Schizophyllum commune, Termitomyces clypeatus, T. robustus, Termitomyces sp. 1, Termitomyces sp. 2, and Volvariella volvacea. Twelve of the identified macrofungi were consumed as food while Ganoderma lucidum and Mycena sp. were used as house decoration and medicine, respectively. The Aeta communities also performed rituals prior to the collection of these mushrooms, including tribal dancing, praying and kissing the ground. Their indigenous beliefs regarding mushrooms are also documented. This is the most extensive enthnomycological study on the Aeta communities in the Philippines.

Key words - edible fungi - ethnomycology - indigenous communities - macrofungi

\author{
Article Information \\ Received 8 March 2012 \\ Accepted 6 April 2012 \\ Published online 30 April 2012 \\ *Corresponding author: tedelacruz@mnl.ust.edu.ph / thomasdelacruz@yahoo.com
}

\section{Introduction}

The Philippines is a culturally diverse country with an estimated 12-15 million indigenous people (IPs) belonging to 110 ethno-linguistic groups (Waddington 2002). The indigenous people constitute $10-15 \%$ of the population of the country. They are mainly found in Northern Luzon and Mindanao, with some groups in the Visayas area (UNDP 2010). Among the major groups of IPs are the Igorot of Northern Luzon, the Lumads of Mindanao, the Mangyans of Mindoro, and the Negritos living in different regions of the country. The Negritos migrated from mainland Asia and settled in the Philippines around 30,000 years ago (Cariño 2010). Their main tribal groups include the Ati found in Panay, the Agta in Bicol, and the Aeta in Luzon.

The Aetas of Luzon are nomadic people. Their social activities revolve around hunting of birds, frogs, and other animals, and gathering of fruits, insects, and mushrooms (Shimizu 1989). Mushrooms also provide additional incomes to households if sold in 


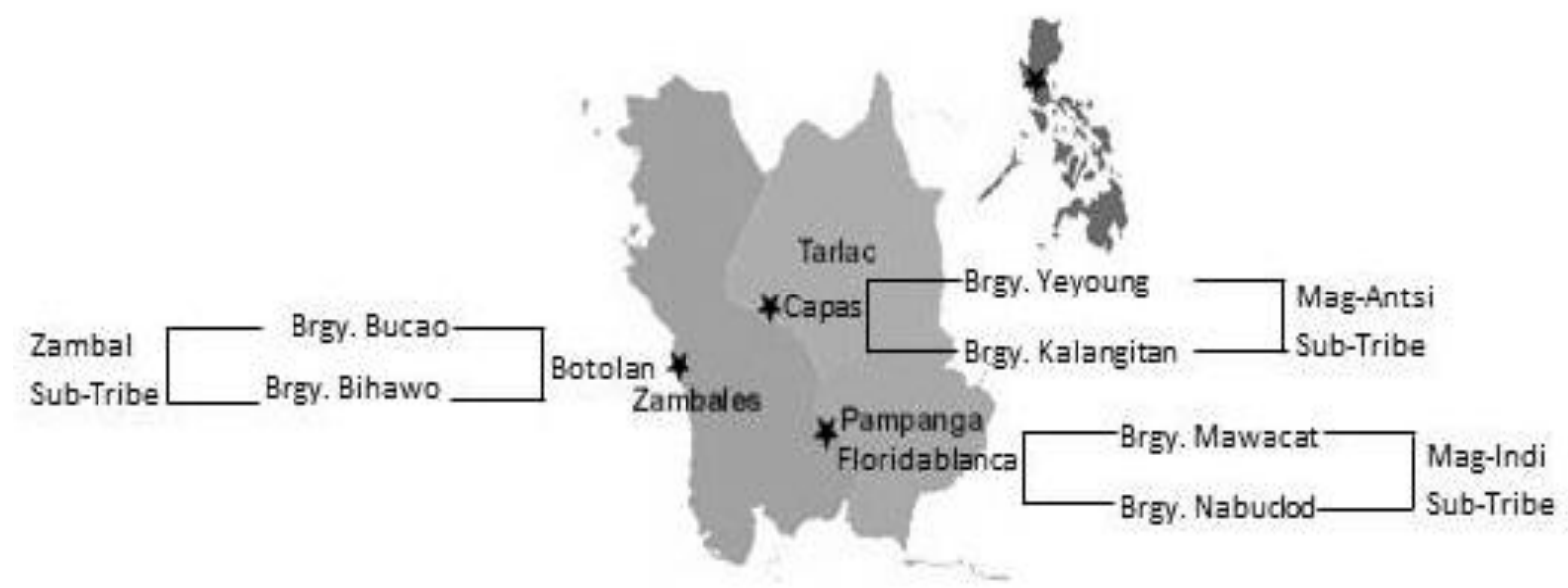

Fig. 1 - Map of Central Luzon showing the three study sites.

(1) Floridablanca, Pampanga:

Site 1: Brgy. Mawacat (14 $\left.58^{\prime} 26^{\prime \prime} \mathrm{N}, 120^{\circ} 26^{\prime} 9^{\prime \prime} \mathrm{E}, \mathrm{AD}\right)$, Aeta population is 1,500.

Site 2: Brgy. Nabuclod (15० 1' 1" N, 120 26' 36" E, RA), Aeta population is 620 .

The Aeta sub-tribe living in this province are the Mag-indi.

(2) Capas, Tarlac:

Site 1: Brgy. Yeyoung (15 19' 32" N, $\left.120^{\circ} 25^{\prime} 1^{\prime \prime} \mathrm{E}, \mathrm{AD}\right)$, Aeta population is 396.

Site 2: Brgy. Kalangitan (15 18' 46" N, $\left.120^{\circ} 31^{\prime} 11^{\prime \prime} \mathrm{E}, \mathrm{RA}\right)$, Aeta population is 2,940.

The sub-tribe of the Aetas in this province are the Mag-antsi.

(3) Botolan, Zambales:

Site 1: Brgy. Bucao (15 $\left.15^{\prime} 28^{\prime \prime} \mathrm{N}, 120^{\circ} 1^{\prime} 51^{\prime \prime} \mathrm{E}, \mathrm{AD}\right)$, Aeta population is 1,570.

Site 2: Brgy. Bihawo (15 $\left.19^{\prime} 8^{\prime \prime} \mathrm{N}, 120^{\circ} 2^{\prime} 46^{\prime \prime} \mathrm{E}, \mathrm{RA}\right)$, Aeta population is 1,020.

Aeta communities in this province belong to the sub-tribe Zambal.

regional markets (Yongabi et al. 2004). In the Philippines, IPs were known to utilize macrofungi species for various purposes (Tayamen et al. 2004). However, few published reports document the exact number of macrofungi utilized by these communities. Hence, their indigenous knowledge is poorly documented and not systematically recorded. It is therefore of urgency to properly document this traditional knowledge before it is lost. Thus, our study surveyed and documented the utilization of macrofungi by six Aeta communities in selected areas of Central Luzon.

\section{Methods}

\section{Study Sites}

Six sites in three provinces (Pampanga, Tarlac and Zambales) in Central Luzon,
Northern Philippines served as the study sites (Fig. 1). In each province, one of the study communities surveyed was Aeta tribe in their ancestral domain (AD) while the other tribe was in a resettlement area (RA). Those in the resettlement areas were Aetas displaced by the eruption of Mt. Pinatubo in 1991.

\section{The respondents}

The Aetas are the earliest inhabitants of the Philippines. Their estimated population is around 140,500 individuals. In Central Luzon, they dwell mainly on mountain slopes in the provinces of Bataan, Nueva Ecija, Pampanga, Tarlac, and Zambales. Many of the Aetas living in Nueva Ecija and some towns in Pampanga, Tarlac and Zambales previously lived on the slopes of Mt. Pinatubo but were now in resettlement areas. They regarded the mountain, as the home of their supreme deity, 
Table 1 Socio-demographic profiles of the surveyed six Aeta communities in Central Luzon, Northern Philippines.

\begin{tabular}{|c|c|c|c|c|c|c|c|c|c|c|c|c|c|c|c|c|c|}
\hline \multirow[b]{2}{*}{ Province } & \multirow[b]{2}{*}{ Study Site } & \multirow[b]{2}{*}{ Sub-Tribe } & \multirow{2}{*}{$\begin{array}{c}\text { No. of } \\
\text { Respondents }\end{array}$} & \multirow{2}{*}{\multicolumn{2}{|c|}{$\begin{array}{cc} & \text { Age } \\
16- & 26- \\
25 & 45 \\
\end{array}$}} & \multirow[b]{2}{*}{$\begin{array}{l}\text { 46- } \\
\text { up }\end{array}$} & \multicolumn{2}{|c|}{ Gender } & \multicolumn{2}{|c|}{ Civil Status } & \multicolumn{5}{|c|}{ Educational Attainment } & \multicolumn{2}{|c|}{ Religion } \\
\hline & & & & & & & Male & Female & Married & Single & College & Vocational & $\begin{array}{c}\text { High } \\
\text { School } \\
\end{array}$ & Elementary & $\begin{array}{c}\text { No } \\
\text { Ans. }\end{array}$ & Catholic & $\begin{array}{c}\text { Non- } \\
\text { Catholic }\end{array}$ \\
\hline \multirow[t]{2}{*}{ Pampanga } & Mawacat & Mag-Indi & 30 & 2 & 20 & 8 & 26 & 4 & 26 & 4 & 0 & 0 & 1 & 12 & 17 & 21 & 9 \\
\hline & Nabuclod & Mag-Indi & 30 & 15 & 13 & 2 & 3 & 27 & 27 & 3 & 1 & 0 & 5 & 16 & 8 & 8 & 22 \\
\hline \multirow[t]{2}{*}{ Tarlac } & Yeyoung & Mag-Antsi & 30 & 9 & 12 & 9 & 11 & 19 & 21 & 7 & 2 & 0 & 6 & 10 & 12 & 0 & 30 \\
\hline & Kalangitan & Mag-Antsi & 30 & 0 & 21 & 9 & 21 & 9 & 27 & 3 & 3 & 2 & 10 & 15 & 0 & 11 & 19 \\
\hline \multirow[t]{2}{*}{ Zambales } & Bucao & Zambal & 30 & 8 & 12 & 10 & 12 & 18 & 25 & 5 & 0 & 1 & 12 & 16 & 1 & 20 & 10 \\
\hline & Bihawo & Zambal & 30 & 5 & 14 & 11 & 6 & 24 & 27 & 3 & 1 & 0 & 4 & 21 & 4 & 26 & 4 \\
\hline
\end{tabular}

Table 2 Survey on the knowledge of mushroom by the six Aeta communities in Central Luzon, Northern Philippines.

\begin{tabular}{|c|c|c|c|c|c|c|c|c|c|c|c|c|c|c|c|c|}
\hline \multirow[t]{2}{*}{ Province } & \multirow[b]{2}{*}{ Site } & \multirow[b]{2}{*}{ Sub-Tribe } & \multirow[b]{2}{*}{$\begin{array}{c}\text { No. of } \\
\text { Respondents }\end{array}$} & \multicolumn{3}{|c|}{$\begin{array}{l}\text { Do you know } \\
\text { Mushroom? }\end{array}$} & \multicolumn{3}{|c|}{$\begin{array}{c}\text { When do mushrooms } \\
\text { appear? }\end{array}$} & \multicolumn{4}{|c|}{ Where do mushrooms appear? } & \multicolumn{3}{|c|}{$\begin{array}{c}\text { How Mushrooms are } \\
\text { Utilized? }\end{array}$} \\
\hline & & & & Yes & No & No Ans. & $\begin{array}{c}\text { When } \\
\text { it's } \\
\text { raining }\end{array}$ & $\begin{array}{l}\text { When } \\
\text { it's hot }\end{array}$ & $\begin{array}{l}\text { When } \\
\text { it's cold }\end{array}$ & $\begin{array}{c}\text { Decaying } \\
\text { Logs }\end{array}$ & $\begin{array}{c}\text { Leaf } \\
\text { Litter }\end{array}$ & Soil & $\begin{array}{l}\text { No } \\
\text { Ans. }\end{array}$ & Food & Medicine & $\begin{array}{l}\text { No } \\
\text { Ans. }\end{array}$ \\
\hline \multirow[t]{2}{*}{ Pampanga } & Mawacat & Mag-Indi & 30 & 25 & 0 & 5 & 30 & 9 & 27 & 27 & 26 & 27 & 1 & 27 & 0 & 3 \\
\hline & Nabuclod & Mag-Indi & 30 & 24 & 4 & 2 & 30 & 0 & 0 & 21 & 3 & 21 & 2 & 29 & 4 & 0 \\
\hline \multirow[t]{2}{*}{ Tarlac } & Yeyoung & Mag-Antsi & 30 & 30 & 0 & 0 & 30 & 0 & 0 & 29 & 1 & 30 & 0 & 30 & 0 & 0 \\
\hline & Kalangitan & Mag-Antsi & 30 & 30 & 0 & 0 & 30 & 4 & 0 & 23 & 23 & 27 & 16 & 30 & 10 & 0 \\
\hline \multirow[t]{2}{*}{ Zambales } & Bucao & Zambal & 30 & 24 & 4 & 2 & 30 & 0 & 0 & 10 & 3 & 25 & 1 & 29 & 2 & 1 \\
\hline & Bihawo & Zambal & 30 & 30 & 0 & 0 & 30 & 0 & 10 & 9 & 1 & 30 & 7 & 30 & 0 & 1 \\
\hline
\end{tabular}


Apo Namalyari. The Aetas are divided into seven sub-tribes according to their dialect. These are: (1) Mag-Indi (Pampanga), (2) MagAntsi (Tarlac), (3) Zambal (Zambales) (4) Ambala (Bataan), (5) Kabayukan (Bataan), (6) Kaunana (Bataan), and (7) Magbekin or Magbukon (Bataan).

\section{Survey Questionnaire and Interview}

Initially, a letter was given to the tribal heads in the study sites requesting permission to conduct research in their areas. A permit was also secured from the National Commission on Indigenous People (NCIP) of the Republic of the Philippines. A meeting was then held with the tribal heads and elders in each of the Aeta communities for the conduct of the survey questionnaires and interview.

Information asked in the questionnaires included: socio-demographic data, knowledge on mushrooms, and beliefs and practices on mushroom collection and cultivation. The survey questionnaires were given to 30 respondents per study site (aged 16 and above). Formatted interviews of the tribal chieftains and other elders were also done to gather more data on the mushrooms they utilized and their traditions. During the collection of specimens, the tribal heads and other members of the tribe including a representative from NCIP joined the field collection and provided additional information.

\section{Collection and Identification of Specimens}

All visibly present macrofungi utilized by the Aeta communities were collected during the rainy season (from May to October 2011) with the assistance of the tribal chieftains and other tribe members. Specimens were initially photographed in their habitat, collected and placed in bags, then taken to the laboratory for identification. For fleshy specimens, samples were preserved in $95 \%$ ethanol. Other specimens, particularly the polypore fungi, were air-dried and prepared as herbarium specimens. Fruiting body morphologies including cap size, cap description, etc. were determined for each of the specimens. A spore print was made from fleshy mushrooms while sectioning was done for non-fleshy mushrooms. Identification was made by comparing morphologies with published literature, e.g., Quimio (2001), Lodge et al. (2004).

\section{Data analysis}

The socio-demographic profiles of the respondents in the six Aeta communities were tabulated to provide basic information on the respondents. The number of identified fungi recorded in the survey questionnaire was determined for each of the sub-tribes. The mushrooms reported in the questionnaires were correlated or compared with the collected specimens. A list of the different fungal species and their local names and utilization was prepared from the study.

\section{Results and Discussion}

\section{Socio-demographic profiles}

Most of the Aeta respondents were 2645 years old, female, married and with Catholicism as their main religion (Table 1). This is also true with most of the IPs found in Northern Luzon (Cabauatan 2008). Many of the respondents also reached only elementary level in their education. This was attributed to poverty. The situation is also very similar with most of the IPs in the Philippines (NCIP 2009).

\section{Indigenous Knowledge on Mushrooms and their Utilization}

Most of the Aeta respondents, regardless of their tribal affiliation and present settlement area, knew about mushrooms (Table 2). All sub-tribes believed that mushrooms appear when it rained. However, three subtribes, i.e. the Mag-Indi in Brgy. Mawacat, Pampanga, the Mag-Antsi in Brgy. Kalangitan, Tarlac, and the Zambal in Brgy. Bihawo, Zambales, believed that mushrooms appear also during the cold months (DecemberJanuary) and/or hot months (March-April). This observation was supported by Reyes et al. (2003) wherein mushrooms could grow anytime of the year in the Philippines as long as present or growing in moist areas. Tayamen et al. (2004) noted that some species grew only after heavy downfall. The Aeta respondents believed that mushrooms grow in soil, decaying logs, and leaf litter (Table 2). 
Table 3 Mushrooms reported by the Aeta communities in Central Luzon, Northern Philippines based on the survey-questionnaires, interviews, and collected specimens.

\begin{tabular}{|c|c|c|c|c|}
\hline Local Names & Scientific Names & Mag-Indi & Mag-Antsi & Zambal \\
\hline Kuwat Amucao & Volvariella volvacea & - & + & + \\
\hline Kuwat Anglap/Papait & Mycena sp. & + & - & - \\
\hline Kuwat Aray & $\mathrm{nc}$ & - & - & + \\
\hline Kuwat Awili & $\mathrm{nc}$ & + & - & - \\
\hline Kuwat Balite & $\mathrm{nc}$ & + & - & - \\
\hline Kuwat Bayto & $\mathrm{Nc}$ & + & - & - \\
\hline Kuwat Baytuat & $\mathrm{nc}$ & + & - & - \\
\hline Kuwat Bola/Duldul & Calvatia sp. & - & + & - \\
\hline Kuwat Gilatgilatan & Termitomyces clypeatus & - & - & + \\
\hline Kuwat Ginikan/Saging & Volvariella volvacea & + & - & - \\
\hline Kuwat Hanggilit & Schizophyllum commune & - & - & + \\
\hline Kuwat Kahoy & Ganoderma lucidum & - & - & + \\
\hline Kuwat Karael & $\mathrm{nc}$ & - & + & - \\
\hline Kuwat Kasoy & Pleurotus sp. & - & - & + \\
\hline Kuwat Kawayan & Lentinus sajor-caju & + & + & + \\
\hline Kuwat Kikitban & Lentinus tigrinus & - & - & + \\
\hline Kuwat Kogon & $\mathrm{nc}$ & - & - & + \\
\hline Kuwat Kuritdit & Schizophyllum commune & + & - & - \\
\hline Kuwat Kuyog & Termitomyces clypeatus & + & + & - \\
\hline Kuwat Lupa/Uong & Termitomyces clypeatus & - & - & + \\
\hline Kuwat Malakamawey & Termitomyces robustus/ Termitomyces sp. 2 & - & - & + \\
\hline Kuwat Malakamay & Termitomyces robustus/Termitomyces sp. 2 & + & - & - \\
\hline Kuwat Mangga & $\mathrm{ni}$ & - & - & + \\
\hline Kuwat Maya & $\mathrm{Nc}$ & + & + & + \\
\hline Kuwat Mayo & Termitomyces sp. 1 & + & + & + \\
\hline Kuwat Miyapol & Lentinus tigrinus & + & - & - \\
\hline Kuwat Puking Buykan & $\mathrm{Nc}$ & + & - & - \\
\hline Kuwat Pulelen & $\mathrm{ni}$ & - & - & + \\
\hline Kuwat Punso & Termitomyces clypeatus & + & + & + \\
\hline Kuwat Puyo & $\mathrm{nc}$ & - & - & + \\
\hline Kuwat Susong Biik & $\mathrm{Nc}$ & + & + & - \\
\hline Kuwat Tagyang Biklat & $\mathrm{Nc}$ & + & - & - \\
\hline Kuwat Malabalugbog dagis/Kuling baki & Auricularia auricula/A. polytricha & + & + & - \\
\hline Kuwat Takaclomuwag & $\mathrm{nc}$ & - & - & + \\
\hline Kuwat Takbulaw & $\mathrm{Nc}$ & + & - & - \\
\hline Kuwat Taklabaw & $\mathrm{Nc}$ & + & - & - \\
\hline Kuwat Tangkiki & Auricularia auricula/A. polytricha & - & - & + \\
\hline Kuwat Titiwbaboy & $\mathrm{Nc}$ & + & - & - \\
\hline Total & & 21 & 10 & 19 \\
\hline
\end{tabular}

The Aetas collect mushrooms mainly for food and rarely for medicine and other purposes (Table 2). The cooking method preferred by the Aetas for nearly all edible mushrooms were sautéed or boiled with other vegetables and fermented fish sauce. Unfortunately, there are no other reported researches on the ethnomycology of other IPs in the Philippines so our result cannot be compared to see if other IPs also shares the same beliefs. In Guyana, the cooking method preferred by the Patamona indigenous tribe was steaming the mushroom in leaves collected in the forests (Henkel et al. 2004).

\section{Listing of Mushrooms Utilized by the Aetas}

There were 38 records of macrofungi that are utilized by the different Aeta subtribes: 21 fungal records in Pampanga, 10 in Tarlac, and 19 in Zambales (Table 3). 
However, during the entire duration of the mushroom collection from May to October 2011, only 14 fungal species were encountered, collected and identified (Table 3). Twelve species were utilized as food: Auricularia auricula, A. polytricha, Calvatia sp., Lentinus tigrinus, L. sajor-caju, Pleurotus sp., Schizophyllum commune, Termitomyces clypeatus, $T$. robustus, two species of Termitomyces, and Volvariella volvacea (Table 4).

IPs from the African continent eat about 300 species of fungi (Rammeloo \& Walleyn 1993). Fungal species were also used by indigenous people as food in Mexico (Garibay-Orijel et al. 2006, Montoya et al. 2004), Malaysia (Christensen \& Larsen 2005), and Papua New Guinea (Sillitoe 1995). In Africa, various kinds of wild edible mushrooms were found, of which 15 to 25 species were locally well known and eaten throughout Zambia (Pegler \& Pierce 1980). Many of these were also sold in market places. For example, Auricularia polytricha is consumed in many African regions, more particularly in Nigeria. Other species of edible mushrooms found in Africa included Agrocybe spp., Boletus spp., Canthareullus spp., Calvatia spp., Coprinus spp., Lactaricus kabansus, L. inversus, L. piperatus, L. edulis, Lentinus cladopus, L. squarosulus, L. tuber-regium, Macrolepiota procera, M. zeyheri, Pleurotus squarrosulus, Psathyrella atroumbonata, $P$. candolleana, Russula spp., Schizophyllum commune, Terfezia boudieri, T. claveryi, $T$. pfeilii, Termitomyces microcarpus, T. clypeatus, T. shimperi, T. titanicus, T. auratiacus, $T$. globu-lus, T. eurhizus, T. robustus, Tricholoma loba-yense, T. matsutake, Volvariella volvacea, $V$. esculenta, and $V$. speciosa (Labarere \& Gemini 2000). Of these, A. polytricha, $S$. commune, T. clypeatus, T. robustus, and $V$. volvacea were also reported as edible mushrooms by the Aeta communities (Table 4).

In Zambales, one sub-tribe (Zambal) reported that Ganoderma lucidum was used for house decoration while in Pampanga, a species of Mycena was used as medicine by the subtribe Mag-Indi (Table 5). In Germany, a new metabolite extracted from Mycena sp. was found to be active against bacteria and fungi
(Sheldrik 1990). Ganoderma lucidum, on the other hand, is utilized mostly as medicine and no previous research cites its use as a household decoration.

Twenty-one local names for several mushroom species were used by sub-tribe Mag-Indi, 10 by sub-tribe Mag-Antsi, and 19 by sub-tribe Zambal (Table 3). However, all mushrooms are generally known as "kuwat" by all Aeta sub-tribes and thus, names for specific species of mushrooms always have this term as a prefix.

Interestingly, we observed similarities in local names given to mushrooms (Table 4). For example, Termitomyces sp. 1, which grows only in May, was locally called by all the subtribes as "kuwat mayo". "Mayo" is the local term for the month of May. It is also interesting to note that the different Aeta communities also used different local names for similar species of mushrooms (Table 4). For example, the subtribe Zambal from Zambales used "kuwat gilatgilatan" as local name for Termitomyces clypeatus. On the other hand, sub-tribe MagIndi from Pampanga used "kuwat uong" while sub-tribe Mag-Antsi from Tarlac used "kuwat kuyog" as the local name for this fungal species. They also used same local names for different species of mushrooms, e.g. Termitomyces sp. 2 and Termitomyces robustus were both locally called "kuwat malakamay or kuwat malakamawey" by sub-tribes Mag-Indi (Pampanga) and Zambal (Zambales) (Table 4). This naming of mushrooms by the Aeta communities was based on the substrates where the mushrooms were actually found. Similarly, the Igala people of Nigera named mushrooms according to its features and the substrates where they are found (Ayodele et al. 2011). In our study, Lentinus sajor-caju is known as "kuwat kawayan" since it is found growing in bamboo (Bambusa vulgaris). In the Philippines, "kawayan" is the local name for this species of bamboo. At this time we cannot say the number of mushrooms utilized by the Aeta communities until specimens for the locally given names are all collected and accounted for, which may take several years. However, our study provides baseline information on the species of mushrooms utilized by the Aeta tribes. 
Table 4 Similarities in local names of collected mushrooms utilized by the six Aeta communities in Central Luzon, Northern, Philippines

\begin{tabular}{|c|c|c|c|}
\hline \multirow{2}{*}{ Scientific Name } & \multicolumn{3}{|c|}{ Different Aeta Sub-Tribes } \\
\hline & Mag-Indi & Mag-Antsi & Zambal \\
\hline Auricularia auricular & Kuwat Malabalugbug dagis/Kuwat Kuling baki & Kuwat Malabalugbug dagis & Kuwat Tangkiki \\
\hline Auricularia polytricha & Kuwat Tikbakulaw & Kuwat Malabalugbug dagis & Kuwat Tangkiki \\
\hline Calvatia sp. & - & Kuwat Bola/Kuwat Duldul & - \\
\hline Ganoderma lucidum & - & - & Kuwat Kahoy \\
\hline Pleurotus sp. & - & - & Kuwat Kasoy \\
\hline Lentinus tigrinus & Kuwat Miyapol & - & Kuwat Kikitban \\
\hline Lentinus sajor-caju & - & - & Kuwat Kawayan \\
\hline Mycena sp. & Kuwat Anglap/Kuwat Papait & - & - \\
\hline Schizophyllum commune & Kuwat Kuritdit & - & Kuwat Hanggilit \\
\hline Termitomyces clypeatus & Kuwat Uong/Kuwat Lupa & Kuwat Kuyog & Kuwat Gilatgilatan \\
\hline Termitomyces robustus & Kuwat Malakamay & - & Kuwat Malakamawey \\
\hline Termitomyces sp. 1 & Kuwat Mayo & Kuwat Mayo & Kuwat Mayo/Kuwat Yabot \\
\hline Termitomyces sp. 2 & Kuwat Malakamay & - & Kuwat Malakamawey \\
\hline Volvariella volvacea & Kuwat Saging & Kuwat Amucao & Kuwat Amucao \\
\hline
\end{tabular}

Table 5 Mushrooms utilized by the six Aeta communities in Central Luzon, Northern Philippines.

\begin{tabular}{|c|c|c|c|c|c|c|}
\hline \multirow{2}{*}{ Mushroom } & \multicolumn{2}{|c|}{ Sub-tribe Mag-Indi } & \multicolumn{2}{|c|}{ Sub-tribe Mag-Antsi } & \multicolumn{2}{|c|}{ Sub-tribe Zambal } \\
\hline & Mawacat (AD) & Nabuclod (RA) & Yeyoung (AD) & Kalangitan (RA) & Bucao (AD) & Bihawo (RA) \\
\hline \multicolumn{7}{|l|}{ As Food } \\
\hline Auricularia auricular & + & + & - & - & + & + \\
\hline Auricularia polytricha & + & + & - & - & + & + \\
\hline Calvatia sp. & - & - & + & + & - & - \\
\hline Lentinus tigrinus & + & + & + & + & + & + \\
\hline Lentinus sajor-caju & - & - & - & - & + & + \\
\hline Pleurotus sp. & - & - & - & - & + & + \\
\hline Schizophyllum commune & + & + & - & - & + & + \\
\hline Termitomyces clypeatus & + & + & + & + & + & + \\
\hline Termitomyces robustus & + & + & - & - & + & + \\
\hline Termitomyces sp. 1 & + & + & + & + & + & + \\
\hline Termitomyces sp. 2 & + & + & - & - & + & + \\
\hline Volvariella volvacea & + & + & + & + & + & + \\
\hline \multicolumn{7}{|l|}{ As Medicine } \\
\hline Mycena sp. & - & + & - & - & - & - \\
\hline \multicolumn{7}{|l|}{ As Decoration } \\
\hline Ganoderma lucidum & - & - & - & - & + & - \\
\hline
\end{tabular}


The number of species utilized by different Aeta tribes varies in relation to their residential sites (Table 5). It is interesting to note that the mushrooms utilized by the Aeta communities in their ancestral domains were also utilized by the sub-tribes who now live in the resettlement areas. This shows that the subtribes that resettled in different communities other than their ancestral domains still observe their customs and beliefs on mushrooms and utilized the same species of mushrooms they once used in their ancestral homes. Their utilization of these species remained the same. For example, $T$. clypeatus was used as food by all three sub-tribes living in their ancestral domains. The same species were also used as food by other sub-tribes presently living in the resettlement areas.

\section{Indigenous Beliefs on Mushroom Cultivation and Utilization}

The different Aeta sub-tribes are also governed by different indigenous beliefs when it comes to mushroom collection, utilization, and cultivation. Some of their indigenous knowledge was as follows:

(1) They do not cook mushrooms together with yellow or red vegetables or with shrimps, fish, and snails as eating these cooked food could cause fatal sickness.

(2) One large mushroom species identified only as belonging to the genus Termitomyces is believed to be guarded by supernatural beings. Thus, before collecting this mushroom, subtribe Mag-Indi performs dancing rituals or asks permission from the spirits and kisses the ground.

(3) Sub-tribe Zambal simply thanks their local deity "Apo Namalyari" for the abundance of their collected mushrooms.

(4) Sub-tribe Mag-Antsi in Tarlac forbids combing their hair and singing while cooking mushrooms. They believed this could attract lightning to strike the person.

(5) Sub-tribe Zambal also mentioned that they should not observe the development of mushrooms on the ground as the mushroom will not continue to grow.

(6) Interestingly, all Aeta sub-tribes believed that spontaneous lightning causes the growth of mushrooms. Such a belief was also known in
Japanese farming folklore (Ryall, 2010). In fact, researchers in northern Japan bombarded a variety of mushrooms in lab-based garden plots with artificially induced lightning to see if electricity actually makes the fungi multiply (Ryall, 2010).

(7) The Aeta sub-tribes also believed that mushrooms grow where the water used to wash or clean mushrooms was thrown. This is expected since mushroom spores present in the washed water would germinate and form fruiting bodies.

In summary, 38 macrofungi were recorded by the six Aeta sub-tribes in Pampanga, Tarlac and Zambales. Only 14 species of these reported mushrooms were collected and identified. The Aeta sub-tribes used these mushrooms as food, as medicine or as household decoration.

Interestingly, the Aetas used similar common names for different species of mushrooms since naming of the species was based on their substrates. All sub-tribes used the same species of mushrooms when living in their ancestral homes or in resettlement areas. Our study highlighted the importance of enthnomycological studies in preserving the indigenous knowledge of our indigenous people.

\section{Acknowledgements}

This research project is supported by a dissertation grant given by the Commission on Higher Education (CHED), Republic of the Philippines. The authors thank Dr. Cristina Binag, Research Center for Natural and Applied Sciences, UST and Dr. Sofronio Kalaw, Center for Tropical Mushroom Research and Development, CLSU for their assistance in the conduct of this study. We also thank Mr. Sallong Sunggod and the staff of the National Commission on Indigenous People (NCIP) for their assistance during the field collection.

\section{References}

Ayodele SM, Akpaja EO, Adamu Y 2011 Some edible and medicinal mushrooms of Igala Land in Nigeria, their sociocultural and ethnomycological 
uses. International Journal of Science and Nature 2, 473-476.

Cabauatan JG 2008 - Ethnobotanical investigations among the five ethnic groups in the Northern Cagayan Valley. Dissertation University of Santo Tomas, Manila, Graduate School.

Cariño JK 2010 - Country Technical Notes on Indigenous Peoples' Issues Philippines. International Fund for Agricultural Development (IFAD). www.ifad.org.ph

Christensen M, Larsen HO 2005 - How can collection of wild edible fungi contribute to livelihoods in rural areas of Nepal? Journal of Forest and Livelihood 4, 50-55.

Garibay-Orijel R, Cifuentes J, Estrada-Torres A, Caballero J 2006 - People using macrofungal diversity in Oaxaca, Mexico. Fungal Diversity 21, 41-67.

Henkel TW, Aime MC, Chin M, Andrew C 2004 - Edible mushrooms from Guyana. Mycologist 18, 104-111.

Labarere J, Gemini U 2000 - Collection, characterization, conservation and utilization of mushrooms germplasm resources in Africa. The Global Network on Mushrooms. FAO. 17-34.

Lodge DJ, Ammiranti JF, O'dell TE, Mueller GM 2004 - Collecting and describing macrofungi. In: Biodiversity of Fungi: Inventory and Monitoring Methods (eds GM Mueller, GF Bills, MS Foster). Elsevier Academic Press, USA, 128158.

Montoya A, Kong A, Estrada-Torres A, Cifuentes J, Caballero J 2004 - Useful wild fungi of La Malinche National Park, Mexico. Fungal Diversity 17, 115-143.

National Commision on Indigenous People (NCIP) 2009 - List of Indigenous Peoples in the Philippines. http://www.ncip.gov.ph/

Pegler DN, Pierce GD 1980 - The edible mushrooms of Zambia. Kew Bulletin $35,475-491$.

Quimio TH 2001 - Workbook on Tropical
Fungi: Collection, Isolation and Identification. The Mycological Society of the Philippines, Inc., Laguna

Rammeloo J, Walleyn R 1993 - The edible fungi of Africa south of the Sahara. Scripta Botanica Belgica 5, 1-62.

Reyes RG, Abella EA, Quimio TH 2003 - Wild macrofungi of CLSU. Journal of Tropical Biology 2, 8-11.

Ryall J 2012 - National Geographic News. http://news.nationalgeographic.com/ne ws/2010/04/100409-lightningmushrooms-japan-harvest/

Sheldrick WS 1990 - Mycenon, a new metabolite from a Mycena species TA 87202 (basidiomycetes) as an inhibitor of isocitrate lyase. The Journal of Antibiotics 43, 1240-1244.

Shimizu H 1989 - Pinatubo Aytas: Continuity and Change. Manila: Ateneo de Manila Press., pp. 31-40.

Sillitoe P 1995 - An ethnobotanical account of the plant resources of the Wola Region, Southern Highlands Province, Papua New Guinea, Journal of Ethnobiology 15, 201-235.

Tayamen MJ, Reyes RG, Floresca EJ, Abella EA 2004 - Domestication of wild edible mushrooms as non-timber forest products resources among the Aetas of Mt. Nagpale, Abucay, Bataan: Ganoderma sp. and Auricularia polytricha. The Journal of Tropical Biology 3, 49-51.

United Nations Development Programme (UNDP) 2010 - Indigenous Peoples in the Philippines: Fast Facts. www.undp.org.ph

Waddington R 2002 - The Aeta. Retrieved September 1, 2010, from The Peoples of the World Foundation. http://www.peoplesoftheworld.org/text? people $=$ Aeta

Yongabi K, Agho M, Carrera DM 2004 Ethnomycological studies on wild mushrooms in Cameroon, Central Africa. Micologia Aplicada International 16(2), 34-36. 